\title{
Autobiography, Bilingualism and Poetry: Writing in English and French in Canada to Address Personal and Political Challenges
}

\author{
By Marie Vautier*
}

\begin{abstract}
Canada is an officially bilingual country (French and English), although very many languages are spoken freely within its borders. Over the past decades, a growing body of literary Canadian texts have illustrated the ease with which creative writers of autobiographical fiction navigate their bilingual lives. Non-fictional autobiographies in Canada, however, tend to be unilingual. Kathleen Saint-Onge's 2013 autobiography, Bilingual Being: My Life as a Hyphen, published by the prestigious Montreal academic press, McGill-Queen's UP, constitutes an exception to the usual practice. In it, the author recounts her bilingual upbringing in her native Québec City, her subsequent move(s) to anglophone Canada, and her life's work of reconciling childhood sexual abuse with her deliberate exiles (in language, in geography, in religion, and in her body). The text is liberally peppered with poems, references to literary theories, historical discourses and reflections on current affairs. This article provides a brief overview of the literary infrastructures that support bilingual writing in Canada, and then examines Saint-Onge's creative bilingual writing practice as an illustration of the quintessentially Québécois/Canadian acceptance of hybridity, lack of certitude, and the ineffable. It argues that bilingual writing, particularly in the poetic passages of the text, allows the autobiographer to examine and to critically reflect upon her personal past in the context of the troubled politics of her country. Bilingualism (French-English) allows her to reach a psychic level of comfort with the frequently conflictual situations of her past and present, and to tie these encounters to the politics of the fascinating postcolonial country that is Canada.
\end{abstract}

Keywords: Bilingual; Canada; Hybridity; Wanderer, French, English.

\section{Introduction: Setting the Scene}

A much-appreciated postmodern and postcolonial writer from Québec, Jacques Poulin, has entitled one of his recent novels "La traduction est une histoire d'amour [Translation is a love story] (2006)."1 In Canada, a bilingual country, where many people speak both English and French fluently, the question of translation is never far from the subject of our literatures. Usually, English Canadian literature is taught in Departments of English in Canadian universities (études anglaises), and Québécois/French Canadian literature is studied in Departments of French (études françaises). Comparatists argue that

*Professor, Comparative Canadian/Québécois literature, University of Victoria, British Columbia, Canada.

${ }^{1}$ Unless otherwise noted, all translations are by Marie Vautier. My thanks to my colleague, Michael Goulet, for a discussion about living as bilinguals in British Columbia and for introducing me to Kathleen Saint-Onge's work. 
it would be productive if our two main literatures were studied together in notyet-established Departments of the Canadian literatures (in both languages) (Vautier, 2010; 2014). Some of the required infrastructure for this shift is in place. There are bilingual literary journals, such as Canadian Literature/Littérature canadienne on Canada's West Coast (University of British Columbia, Vancouver, B.C.) or Studies in Canadian Literature/Études en littérature canadienne, on the East Coast (University of New Brunswick, Fredericton, N.B.). There are bilingual undergraduate programmes of literary study, such as the one at the University of Victoria (British Columbia), and bilingual graduate degrees in our literatures at research institutions such as l'université de Moncton (New Brunswick) or l'université Sherbrooke (Québec). There are centres for the study of our literatures in both official languages, such as the Canadian Literature Centre/Centre de littérature canadienne at the University of Alberta in Edmonton. Many works of literature are translated from one language to the other (and in many other languages, of course (See Ladouceur, 2012; Mezei et. al, 1988, 2014; Mezei, 2003). There are many bilingual writers of fiction (French-English) and some even write their texts in both languages, within the same book covers without translation: works such as Carole Corbeil's Voice-Over (1992) or Lola Lemire Tostevin's Frog Moon (1994).

Bilingual academics study our literatures and publish their work in our two official languages, as two leading scholars of Québécois literature from the University of British Columbia in Western Canada point out: "Dans ce pays fictivement bilingue, il y a de plus en plus de gens qui le sont réellement et qui publient indifféremment dans les deux langues, quelle que soit la province où ils sont nés ou dans laquelle ils résident [In this fictionally bilingual country, there are more and more people who really are bilingual, and who publish freely in both languages, regardless of the province where they were born or in which they reside]" (Beaudoin \& Lamontagne, 2002, p.20). In 2013, the question of bilingualism and identity took a different turn: the very prestigious McGill-Queen's University Press published an autobiography by Kathleen Saint-Onge, entitled Bilingual Being: My Life as a Hyphen.

Current studies in autobiography, and in particular women's autobiography, challenge what Paul John Eakin calls "the Gusdorf model," "the province of the Marlboro Man" (1999, pp.47, 49), which emphasizes the long tradition on individualism in masculinist autobiography. These current studies also challenge both versions of Philippe Lejeune's autobiographical pact, which thematize the importance of progress in knowledge of the Self through autobiography (Lejeune, 1988). Eakin argues that all identity is relational and deplores that theories of autobiography have jelled along gender lines: "The three most prominent of these male-female binaries are the individual as opposed to the collective, the autonomous as opposed to the relational, and, in a different register, narrative as opposed to non-linear, discontinuous, nonteleological forms" 1999, p.48). The Canadian theorist of autobiography Helen M. Buss reacts to Eakin's assertion by stating that while "feminist theories of relational identity" have done much to further critical work on autobiography and its related fields (the memoir, in her case), this 
work will not be advanced by efforts to remove or limit the specificity of women's life writing from the critical discourse (Buss, 2002, p.14). The challenge to traditional autobiography occasioned by feminist theories of lifewriting is present in Kathleen Saint-Onge's non-linear work, which combines the urge to knowledge of the self in relation with others with an awareness of the political backdrop that frames her autobiographical publication.

\section{Bilingual Being}

In this remarkable work of non-fiction, the author recounts her bilingual upbringing in her native Quebec City, her subsequent move to anglophone Canada, and her life's work of reconciling childhood sexual abuse with her deliberately chosen exiles (exile in language, in geography, in religion, and in her body). The reflective, autobiographical text is liberally peppered with poems, references to literary theories, historical discourses and reflections on past and current political issues. It is written in English and French.

A forthcoming article written in French examines the multiple ways in which Saint-Onge's text explores the notion of exile (Vautier, n.d.). That research focusses on exile in geography and in language. In that article, the analysis is concentrated mainly on the prose parts of this multi-faceted text, which illustrate, among other talents, Saint-Onge's sardonic skill at manipulating literary theories from both the anglophone and francophone spheres of interest. For instance, discussing the main character in a childhood nursery rhyme- "Chère Élise" in French; "Dear Liza" in English-Saint-Onge riffs on accepted theoretical discourse: "Our young multilingual, multicultural subject is quintessentially postmodern, multiple, fragmented, hybrid, liminal, fluid. A pin-up girl for the times. Chic split" (2013, p.xvi). This ironic tone gives way to a more serious exploration of the past in the prose sections of the autobiographical work, which examine how the author's deliberate efforts to abandon her French language (and related elements) are linked to the longlasting effects of the sexual abuse of the past. In Canada, and perhaps, particularly, in Québec, language, heritage and cultural and personal identities are strongly associated, and the stress of consciously choosing one of the dominant spheres over the other is explored in multiple ways in this autobiography.

The work, Bilingual Being, thematizes the split personality of the québécoise writer in its very presentation. The front cover of the book jacket shows a picture of a young blond girl between the title and subtitle; with one exception, every element on the page is non-aligned separated by a line drawn down the middle of the page. Only the author's name is aligned, but even there, the line separates the anglophone first name from the francophone surname. The text is written in the first person, and tells the life story of Kathleen SaintOnge, born in 1957 to a unilingual francophone mother and a bilingual anglophone father who has French and British ancestry in his family. Using a term that designates "from old stock" in Québécois, Saint-Onge refers to herself a "[une fille] d'la souche" (2013, p.179), and explains that on her mother's side, the family has been in the New World for centuries, and that on 
her father's side, English is the language of usage, as his mother was a British immigrant. The memoirist has a brother, who self-identifies as francophone, many relatives, and two grandmothers who illustrate, each in her own way, how things should be done, which brings a great deal of cultural confusion to the young girl.

Near the beginning of her life, Saint-Onge was sexually abused by two pillars of Québécois society: a senior member of her own family (called "the Elder" in the text) and one of his friends: a Catholic priest. The multiple acts of sexual abuse, repressed until adulthood, had a very strong influence on her linguistic and life choices. The abuse began when she "existed prior to formal language" (Saint-Onge, 2013, p.44), and were imposed upon her body as a baby and a very young girl. From a "toddler with a psychic split" who has "a story that can't ever be told - the absolutely unnarratable" (ibid., p.287), she fled from French, as she says, "into the waiting arms of English" (ibid., p.15). In very francophone Québec City, she finds refuge in her anglophone elementary school: "Marymount College, a private English Catholic school for girls in Sainte-Foy, run by an order of sisters from upper New York State" (ibid., p.31). Gradually, and not without provoking deep tensions within her family and herself, the author neglects her francophone self for life as an anglophone, eventually leaving Québec for a nomadic existence in western and central Canada, where she lives, but not as a "balanced bilingual," as the linguists say:

There is, in fact, nothing balanced about it - no equilibrium, no point where everything is just right. That isn't how bilingualism is lived [...] I walk a thin line between belonging in each language and not belonging at all. I'm different in my languages, [but...] have I acquired the possibility of saying something substantially different [as a bilingual being]? (Saint-Onge, 2013, p.230)

The prose sections of this text, interesting and stimulating as they are in their exposition of literary theories, Québécois politics, family tensions and lucid self-examinations, are not the work's primary site for saying "something substantially different" (ibid., p.230). The interspersed poetic texts are more revelatory of the "unnarratable," and offer a forum for the expression of a differently-focussed viewpoint. ${ }^{1}$ For instance, commenting on the main character of the afore-mentioned nursery rhyme, Élise/Liza, the author easily projects herself into an imagined learned discourse: "Academics might say she has a presentation of self that varies with her languages as her bilingual identities play out like alters, fluctuating and flickering, influenced by the passions of affect, culture, and the primary allegiances of the soul" (ibid., p.xvi). This learned, rational tone is mainly absent from the poetry, which

\footnotetext{
${ }^{1}$ In the epilogue to the work, Saint-Onge notes that the poems are from "another mental space entirely" (2013, p.328), and that they "are crafted from the therapy journal [she] wrote in the months following the confirmation of [her] trauma on 29 August 2010" (2013, p.327).
} 
allows the author to reflect on the French she has fled, as in this piece entitled "Pronoun":

My mother tongue,

French,

is, in a word,

gracious.

It's the language

of the pronoun "on."

[Here follows a substantial list of possible meanings of the pronoun "on," with all examples given in French:

"On" can mean "a nameless person."

As in, "On m'a relié le problème."

Meaning, "Someone (inconsequential) related the problem."

"On" can mean "an omnipresent everyone."

As in, "On oublie ce genre de problème facilement."

Meaning, "This kind of problem is easily forgotten by all."]

$[\ldots]$

The pronoun, "on."

A word that hides identities.

A word that sustains opacities.

A word that allows multiplicities.

A word that obscures responsibilities.

My mother tongue, is,

in a word,

perfect. (Saint-Onge, 2013, p.89)

The "positive" appreciations of the French language ("gracious"; "perfect") come sharply up against the implicit criticism of what happened in French ("hides identities" ; "obscures responsibilities") in this text. This push/pull effect in poetry is an illustration of the complexities that inhabit the bilingual author. It is noteworthy that the list of possible meanings of "on," with examples that refer again and again to "le problème," might be said to camouflage the problem, which is the silence of members of her family regarding the sexual abuse, and the implied tacit acceptance of it.

There are differences between the English and the French in this work. "All my life," notes the autobiographer, "I've run from my mother tongue and from my heritage, seeking shelter in English" (Saint-Onge, 2013, p.50). The French used in the poetry sections (which are without pagination) is often transcribed phonetically, in a textual representation of a casual, oral French, spoken by someone without much formal education. A clear illustration of this type of writing is found in the dedication to the work: 
Pis c'es pour toé surtout, c'te liv'-là,/ma belle cousine Sonya. $[\ldots] C$ 'fa q'ej dédie c'te travail-là bin fort à ton honneur, pis el maudit silence, on l'perce ensemb' astheure (ibid., n.p.)

In regular, grammatical French, this would read: "Et, il est surtout pour toi, ce livre-ci, ma belle cousine Sonya, [...] Cela fait que je dédie ce travail de façon très sincère à ton honneur/et le maudit silence, on le perce ensemble maintenant." The English translation is provided in the text below the phonetically recorded French text, and it is in regular, grammatical English: "[And it's for you most of all, this book,/my beautiful cousin, Soyna/. [...] So I dedicate the present work sincerely in your honour,/and the damned silence, we pierce it now, together.]" The strong contrast between the explanatory passages in English (with their highly regular English usage) and the orality and poor grammar of the type of French used in the poetry sections are indicative of two worlds of the imagination, and two self-portraits. The French is immediate, direct, and rooted in childhood; it instantly transports the bilingual reader into the world-view of the young girl, whereas the colder tone of the grammatically-correct English presents a more distanced view of events of the past.

In another poetry entry, entitled "Definitions," the author brings her internal schism into light succinctly:

I am cut vertically:

right brain for symbols and early language;

left brain for complex language and writing.

$[\ldots]$

I am cut linguistically:

a mother tongue for the little girl I was;

another tongue for the woman I became. (Saint-Onge, 2013, p.143)

This poem, in English, accurately describes the situation of the author, but it does not have the immediacy of a subsequent one, written partially in French, which describes "une p'tite soirée, un p'tit parté": a basement party organized by her mother, wherein the eight-year old author and two young female cousins are dressed as "pretend Playboy bunnies" (ibid., p.173), dispersing cigarettes and treats to the male guests, which include the Elder and members of the "family-friendly" Catholic clergy. Her "job" is to "faire un beau sourire pis servir les hommes" [author's translation: "Make a pretty smile and please the men"]. Unable to refuse the imposed role, the author describes the "[o]lfactory triggers of [her] horror:/men, smoke, tobacco, nicotine" and decries the situation of a "cuture twisted": "C'est juste drôle, ça-là./C'est juste pour faire un peu d'fun/This from my mother's tongue_-/my mother tongue." [author's translation: It's funny, that's all. It's only to have a bit of fun'] (ibid., pp.173175). Her caustic observations are presented in English, but it is the poetry that allows for the articulation of the young girl's prescience: "I am being socially constructed as a slut./Compliant in my best smile,/I vomit only on the inside" (ibid., p.175). The autobiographical text returns repeatedly to the different 
attitudes to sexuality espoused by francophone and anglophone women in Canada, and the author outlines her refusal of "French acculturation" (ibid., p.185) by detailing the tension between herself and her mother, as she refuses her mother's typical embracing of feminine sexuality:

I was instinctively determined not to be 'une belle poupée' [a pretty doll] on display for all to see [...] So I resisted the French-Canadian version of the feminine without understanding why, except for the vaguest notion that in dressing me up and promoting my sexuality, my mother was setting me up. (ibid., p.190)

The author clearly remembers her choice of "self-othering": at the age of five, after waking up "feeling a horribly familiar bodily and spiritual disorientation" (ibid., p.159), she decides to learn English well as a "way out" of her horrific situation. As she says in a prose section: "for a victim of sexual trauma in one particular language, the potential for rebranding in another language is dramatic -an invitation that can't be refused" (ibid., p.190). Speaking (out) in English is seen as her resistance to the rule that dominated her home life: "“dis pas un mot à personne' [Don't tell a word to anyone]" (ibid., p.210). However, the entire autobiography articulates that a deliberate choice of language and its implicit accompanying identity does not erase the tensions involved in making that choice.

In first-generation postcolonial studies, such as those espoused by Helen Tiffin and Bill Ashcroft out of Australia, a contestatory attitude is evident in the idea that former European colonies are the margins that "writ[e] back" to the centre, setting up, in that process, binary oppositions and cultural conflicts (Ashcroft et al., 1989, n.p.). The literary and cultural theorist Homi Bhabha develops the concepts of hybridity and a "third space" in his approach to postcolonialism, wherein separate entities come into contact, producing, in the colonized, a hybrid of their own cultural identity and that of the colonizer's. ${ }^{1}$ In Canada, in works that fall under the umbrella-term "second-generation postcolonialists," scholars such as Rowland Smith explore an alternate approach - that of "side-by-sidedness" - which proposes "the possibility of sharing cultural experience rather than 'resisting' the imposition of alien forms of culture" (Smith, 2000, p.4). All of these scholars, however, still see the elements studied originally as separate entities which eventually go beyond contestation to transcultured moves that share experiences. What happens, then, when the duality is anchored within a single bilingual being? How does one negotiate omnipresent, internal side-by-sidedness, such as that known and experienced at a deep level from a young age, as opposed to being introduced from "outside" ?

The life of the author of Bilingual Being is set against a backdrop of the highly charged political events in Québec/Canada in the 1950s and 1960s, with Saint-Onge frequently referring to the energetic political (and linguistic)

\footnotetext{
${ }^{1}$ See Rutherford, J. (1990) for a detailed discussion and analysis of Bhabha's "third space."
} 
skirmishes of the time (See Vautier, n.d.). Quotations that link her bilingual internal tensions to political events permeate the text. For instance, she states:

I can't help but be aware of the bilingual spectacle that's in me, that is me. [...] I'm a French-Canadian female, a child of the 1950s, of eligible age just in time for the election of the PQ [Parti Québécois] to provincial power in 1976, the first election in which I ever voted-but too far gone towards the edge of the world, in every way, to come back to Quebec from Victoria, British Columbia, twenty years later, to vote in the critical provincial referendum of 1995. (Saint-Onge, 2013, p.15)

It is as though the fact of her being bilingual and in a country with very strong "language politics" makes of her a from-the-inside, permanently nonfixedly-determined individual. She senses this: «Irreconcilable, you say? Incoherent? No, just messy. [...] I'm an unsettled flux of loyalties. I embrace my English intellect, my escape. But I hold dearly to my French soul, too" (ibid., p.147). Like Edward Said's "wanderer"-someone who is "essentially between homes," who faces "constant transposition [...] 'exteriority' and 'inbetweeness"' (Said, 1975, p.8), Saint-Onge's work illustrates how one lives one's internal complexities as a "bilingual being." "In word and deed," she writes, "I'm 'une Canadienne errante' [a Canadian wanderer], like the famous song says" (Saint-Onge, 2013, p.29). ${ }^{1}$ This autobiographical text reflectively meditates upon the fact that moving between languages and cultural identities allows the author to overcome the challenges of her early sexual abuse. It also celebrates how being a permanent wanderer allows for a constantly shifting appreciation of self. As she notes:

... in each of my languages, I'm embodied in a particular view of the feminine. And these different perceptions of my gendered self-my variant possibilities as a woman in each culture - have distinctively affected my linguistic undertaking. In choosing a language and its world, I effectively select a particular version of myself as a woman. (Saint-Onge, 2013, p.190)

Furthermore, beyond her celebration of continual adaptable and flexible mouvance in her gendered and sexual identities, she also sees herself as an embodiment of the worlds in which she navigates. In many passages, the author ties her life to that of the constantly-changing political landscapes of the country: "can someone ever be bilingual and bicultural without becoming a political being [...]? And have I, in fact, lived a quite political life 'incidentally,' as my granny was so fond of saying?' (ibid., 2013, p.161).

Near the beginning of the work, the memoirist describes herself in somewhat negative terms as a "drifter-spiritually, geographically, and linguistically" (ibid., p.43). Toward the end of the text, however, the author

\footnotetext{
${ }^{1}$ See Fowke, E. et al. (1961) for the original text of the masculine-inscribed "Un Canadien errant," a well-known politically-motivated French Canadian folk song.
} 
acknowledges that the "bilingual is a complicated hyphen. In French, 'un trait d'union': a connection, a line between" (ibid., p.240). Seeing her own life as "a human hyphen" (ibid., p.243), the author presents her bilingualism and that of members of her family in more positive terms. Discussing a recent bilingual family gathering, she notes "we were way past thinking about so-called codeswitching. The switch was the code as we negotiated meaning within our wide expanse of possibilities in both directions" (ibid., pp.312-13). In fact, it is in the "perpetual, paradoxical tension" (ibid., p.302) of moving from "being bilingual to [being a] bilingual being (ibid., p.323, [italics in the original])" that the author finds her element:

... my languages aren't the two irreconcilable solitudes Canadian politicians often make them out to be. Rather, they're the flexible contours of a psychological space stretched out before me where I enact a most sufficient life not just upon it but because of it. For in the topography of my bilingual mind, English and French are the shores of the syncretic sea I inhabit - the essence in which I turn and return. (ibid., p.302)

This most interesting autobiography details the difficulties, challenges and rewards of one case of internal side-by-sidedness; many more such cases exist in the bilingual country that is Canada.

\section{Conclusion}

In her contribution to Tendances actuelles en histoire littéraire canadienne (Saint-Jacques, 2003), Kathy Mezei provides a succinct historical overview of English-French literary translation in Canada, and the political underpinnings of such work at the beginning of the twenty-first century (Mezei, 2003). She dwells on the typically Canadian reflections on the act of translation; the classic exchanges between Anne Hébert and her translator, the poet F. R. Scott, are perhaps exemplary of this mode of work (Hébert \& Scott, 1970). Mezei also mentions briefly more contemporary "self-translations" of a few of Canada's bilingual writers of fiction, such as Nancy Huston, who "re-writes" her own novels in our second official language (Huston 1993a was rewritten as Huston 1993b); or creative writers who, like Huston, are "personal embodiment[s] of bilingualism": "poet/novelist Lola Lemire Tostevin or writer/translator Susanne de Lotbinière-Harwood," to name but two wellknown names in feminist bilingual circles (Mezei, 2003, p.119). Although Mezei's double focus is on the history of literary translation in Canada and on the shift in attitudes about translation-from its conceptualization as an "oppositional binary [...to] a more fluid [act] expressed through conversation, dialogue, and collaboration" (ibid., pp.111-112) - she makes no mention of bilingual autobiographies. Neither does an extensive and definitive contemporary work edited by Julie Rak, Auto/biography in Canada: Critical 
Directions (2005). It is very possible that Saint-Onge's text, with its mixity of languages, personal memories, historical facts, poems and reflections on being a bilingual being is a "new" phenomenon in Canadian autobiography. Undoubtedly, her creative bilingual writing practice is an illustration of the quintessentially Québécois/Canadian acceptance of hybridity, lack of certitude, and the ineffable.

As Rak, Mezei, and many others have noted, the extensive work done by bilingual feminists writers, who are often "translators" of both text and meaning in Canada, has strongly impacted "the study of auto/biography" (Rak, 2005 , 14). The appearance of this multifaceted work by Kathleen Saint-Onge may be seen as one possible outcome of the groundwork provided by bilingual authors of fiction and scholars of feminist and postcolonial bilingual texts in Canada.

*An earlier version of this article was published in the ATINER series: Vautier, M. (2015)."Performing Bilingualism in Canada: Writing Autobiographically in English and French to Address Hybridity's Challenges", Athens: ATINER'S Conference Paper Series, No. ART2015-1532.

\section{References}

Ashcroft, B., Griffiths, G., \& Tiffin, H., 1989. The empire writes back: theory and practice in post-colonial literatures. London: Routledge.

Beaudoin, R., \& Lamontagne, A., 2002. Un demi-siècle de réception critique de la littérature québécoise au Canada anglais: 1939-1989. Canadian Literature, no. 175 , pp. $19-41$.

Buss, H. M., 2002. Repossessing the world: reading memoirs by contemporary women. Waterloo, Ont: Wilfrid Laurier University Press.

Corbeil, C., 1992. Voice-over. Toronto: Stoddart.

Eakin, P. J., 1999. How our lives become stories: making selves. Ithaca, N.Y.: Cornell University Press.

Fowke, E., Mills, A., \& Blume, H., 1961. Un Canadien errant. Canada's story in song. Toronto: W.J. Gage, pp. 82-4.

Gusdorf, G., 1980. The Conditions and Limits of Autobiography. In: J. Olney ed. Autobiography, essays theoretical and critical. Princeton, N.J.: Princeton University Press, pp. 28-48.

Hébert, A., \& Scott, F. R., 1970. Dialogue sur la traduction: à propos du tombeau des rois. Montréal: $\mathrm{HMH}$.

Huston, N., 1993a. Plainsong. Toronto: HarperCollins.

Huston, N., 1993b. Cantique des plaines: roman. Montréal: Leméac.

Ladouceur, L., \& Lebeau, R., 2012. Dramatic licence: translating theatre from one official language to the other in Canada. Edmonton, AB: University of Alberta Press.

Lejeune, P., \& Eakin, P. J., 1988. On autobiography. Minneapolis: University of Minnesota Press. 
Lotbinière-Harwood, S. D., 1991. Re-belle et infidèle: la traduction comme pratique de réécriture au féminin = The body bilingual: translation as a re-writing in the feminine. Montréal: Éditions du Remue-ménage.

Mezei, K., 2003. Dialogue and Contemporary Literary Translation. In: D. SaintJacques, ed. Tendances actuelles en histoire littéraire canadienne. Québec: Editions Nota Bene, pp. 107-129.

Mezei, K., Matson, P., \& Hole, M., 1988. Bibliography of criticism on English and French literary translations in Canada, 1950-1986: annotated. Ottawa: University of Ottawa Press.

Mezei, K., Von Flotow, L., \& Simon, S., 2014. Translation effects: the shaping of modern Canadian culture. Montreal and Kingston: McGill-Queen's University Press.

Poulin, J., 2006. La traduction est une histoire d'amour: roman. Montréal: Leméac.

Rak, J., 2005. Auto/biography in Canada critical directions. Waterloo, Ont: Wilfrid Laurier University Press.

Rutherford, J., 1990. The Third Space: Interview with Homi Bhabha. In: Identity: Community, Culture, Difference. London: Lawrence and Wishart, pp. 207-221.

Said, E. W., 1975. Beginnings: intention and method. New York: Basic Books.

Saint-Jacques, D., 2003. Tendances actuelles en histoire littéraire canadienne. Québec: Editions Nota Bene.

Saint-Onge, K., 2013. Bilingual being: my life as a hyphen. Montreal: McGill-Queens University Press.

Smith, R., 2000. Postcolonizing the Commonwealth:studies in literature and culture. Waterloo, Ont: Wilfrid Laurier University Press.

Tostevin, L. L., 1994. Frog moon. Dunvegan, Ont: Cormorant Books.

Vautier, M., 2010. Comparative Canadian/Québécois literature: the way of the future? Canadian Literature, no. 204, pp.152-5.

Vautier, M., 2014. Comparative Canadian/Québécois literature studies. In: R. Nischik. The Palgrave handbook of comparative North American literature, pp. 129-147.

Vautier, M., n.d. L'exil dans la langue et le pays : une analyse de Bilingual Being: My Life as a Hyphen de Kathleen Saint-Onge (McGill-Queen's, 2013). Forthcoming Canada. 
